\title{
A INCORPORAÇÃO DE NARRATIVAS PESSOAIS NO WEBJORNALISMO: a construção de uma história a partir de postagens do Facebook
}

\author{
Silvana Copetti Dalmaso ${ }^{1}$
}

Resumo: O Facebook se transformou em ferramenta geradora de narrativas para o jornalismo. Este artigo discute as apropriações de postagens na construção das notícias a partir de um episódio ocorrido em 2017: a suspensão das atividades da banda gaúcha Apanhador Só devido a um post no Facebook. Por meio da Análise de Conteúdo, examinamos como três notícias, dos sites dos jornais Folha, Estadão e O Globo, utilizaram postagens do site de rede social para construir seus relatos noticiosos sobre o caso. O objetivo é discutir se e como as formas de captura desses dados pelo jornalismo podem modificar eventuais compreensões das notícias.

Palavras-chave: Jornalismo; narrativa; redes sociais digitais; Facebook

\begin{abstract}
The Facebook became a creator tool of narratives to journalism. This article discuss the use of these narratives approaching a specific case occurred in 2017: the activities cancellation of the band Apanhador Só due to a Facebook post. In order to do that, we took Content Analysis and analyzed how news from Folha, Estadão and $O$ Globo newspapers websites use the Facebook posts in their stories about the case. The aim is to discuss how the ways of capture of these informations by journalism can change the news comprehension .
\end{abstract}

Keywords: journalism; narrative; social networks; Facebook.

\section{Introdução}

Os sites de redes sociais, e todo o feixe de conexões e mensagens que permitem visualizar, já fazem parte da dinâmica de construção das notícias do webjornalismo. Plataformas de mídia social como Facebook, Instagram e Twitter, além de acelerar a circulação e compartilhamento das matérias noticiosas (BRUNS, 2014), também são geradores de matéria prima informativa para os veículos jornalísticos.

O jornalismo, conforme Franciscato (2005), ao produzir os relatos sobre o tempo presente, transforma o ambiente histórico e social mas também é influenciado pelo seu entorno e pelas tendências sociais da contemporaneidade, "é afetado por novos fluxos de informação, hábitos de leitura e interação social, tendo que redefinir seus modos de atuar socialmente" (2005, p.165). Os sites de redes sociais fazem parte dessas mudanças transformadoras do cotidiano que envolvem o jornalismo. Na internet, a produção jornalística está circundada pela velocidade e urgência no acompanhamento dos eventos (BRADSHAW, 2014). A atualização das notícias no ambiente online é contínua (BASTOS, 2012) e os websites dos jornais, por exemplo, alimentam rapidamente suas páginas nos sites de redes

\footnotetext{
${ }^{1}$ Graduada em Jornalismo e Letras pela UFSM, Mestre em Comunicação Midiática pela UFSM, doutora em Comunicação e Informação pela UFRGS.
} 
sociais cujo fluxo de circulação de informações é veloz, quase ininterrupto. O jornalismo, assim, precisa dar conta de uma demanda cada vez maior por conteúdos para atender a uma audiência mais ativa (MASIP et al., 2015), participativa em diversas plataformas (GONZÁLEZ, 2010) e que possui um papel significativo na avaliação das notícias (SHOEMAKER et al., 2010).

Com a multiplicação dos canais de informação e a ampliação das formas de produção e distribuição de conteúdo informacional (LEMOS; LEVY, 2010), o jornalismo multiplataforma (HEINRICH, 2011) passa a ter acesso facilitado a esses lugares de compartilhamento de narrativas diversas, como os sites de redes sociais. O jornalismo, de acordo com Heinrich (2011), passa a conviver com mais atores que tomam parte do processo de produção de notícias e fazem mais informação ser posta em circulação.

Nesse sentido, a narrativa jornalística passa a contar com a interação e o engajamento da audiência de forma pública e imediata. As narrativas pessoais, que se produzem diariamente nestes espaços de conversação pública que são os sites de redes sociais digitais (RECUERO, 2014), ficam disponíveis ao jornalismo. O discurso jornalístico passa a incorporar aos seus próprios relatos do mundo essas histórias publicadas por pessoas e grupos. O webjornalismo, que se consolidou por meio da hipertextualidade da linguagem e uso de bases de dados (MACHADO, 2006), anexando materiais e hiperlinks para outros endereços da internet, captura essas narrativas pessoais das redes sociais para produzir suas notícias, citando, comentando, referenciando e hiperlinkando testemunhos postados em perfis e páginas desses sites.

Cotidianamente, os sites jornalísticos nos apresentam notícias que contêm informações ou imagens retiradas de perfis pessoais de sites de redes sociais, como o Facebook, o Instagram ou o Twitter. Quando se trata de personalidades públicas, principalmente, suas contas nessas redes transformam-se em fontes oficiais para o jornalismo, que retira desses espaços os dados que lhe importam que virem notícia. Declarações de presidentes de estado, publicadas no Twitter, são lidas por apresentadores de telejornais de todo o mundo, por exemplo. Vídeos amadores postados no Youtube com imagens de flagrantes importantes ou de catástrofes naturais tornam-se material utilizável pelo jornalismo (ANDERSON, BELL, SHIRKY, 2013), fotografias são agora retiradas dos perfis pessoais nas redes sociais para serem expostas nas notícias; ou seja, há uma transposição narrativa de imagens que se deslocam do universo das redes sociais para as páginas dos veículos jornalísticos na internet. 
Os canais pessoais se transformaram em fonte de informação com importância e valor correspondentes a documentos, entrevistas, comunicados oficiais etc. A busca, de parte do jornalismo, por materiais nesses espaços já faz parte da rotina de produção e construção das notícias até mesmo porque os produtores de mensagens, as fontes de informações, que também são gatekeepers, no sentido estudado por Shoemaker e Vos (2011), já se habituaram a usar as redes sociais como canais oficiais de comunicação.

Além de atuarem como potenciais espaços agregadores e gestores de conteúdo alheio, produzido por organizações e usuários (NOGUERA VIVO, 2010), os sites de redes sociais geram eventos e notícias. Esses ciberacontecimentos (HENN, 2013), que são replicados, comentados e compartilhados na internet, oferecem ao jornalismo narrativas que podem ser agregadas à construção das notícias. Se estes dados estiverem dispersos ou fragmentados em perfis pessoais das redes sociais, cabe ao jornalismo organizar essas falas e compor uma narrativa única que faça sentido ao leitor. As publicações jornalísticas sobre esses ciberacontecimentos, por sua vez, são também postas em circulação e compartilhadas pelo público, configurando o que Zago (2014) define como uma recirculação de narrativas do acontecimento no jornalismo em rede.

No Facebook, fotografias, vídeos, depoimentos, testemunhos, acusações e retratações se tornam públicos pelos seus usuários e nesse momento se transformam em matéria prima para o jornalismo, especialmente para os websites de veículos. Ao capturarem essas narrativas do Facebook, os veículos jornalísticos agem como os usuários da internet que buscam informações, dentro do paradigma pull; ou seja, puxam os dados disponíveis na rede (PARISER, 2012) e os inserem nos relatos noticiosos; essa prática faz com que muitos jornais acabem dispensando a procura direta pelos envolvidos, pois as informações de que necessitam ou julgam necessitar já estão "dadas”.

Diante desse quadro, o objetivo deste artigo é discutir de que forma as narrativas pessoais publicadas no Facebook são utilizadas pelos textos jornalísticos a partir de um ciberacontecimento específico ocorrido em agosto de 2017: o cancelamento das atividades da banda gaúcha Apanhador Só depois de uma postagem, no referido site de rede social, da exmulher de um dos integrantes do grupo. Por meio dos suportes metodológicos da Análise de Conteúdo (BARDIN, 2011), que permite a leitura flutuante, descrição, categorização e interpretação de textos, examinamos três notícias publicadas no dia 17 de agosto de 2017 pelos websites do jornais $O$ Globo, Estado de S.Paulo e Folha de S.Paulo referentes ao 
episódio a fim de verificar como as narrativas postadas do Facebook - de autoria da exmulher, do músico citado e da banda - foram inseridas nas construções textuais jornalísticas. Nesse exame, focamos nos fatos mais destacados pelos jornais, ou seja, o que foi citado, filtrado e tomado como mais relevante desses depoimentos, a construção lexical do título e suas implicações, e a inserção ou não, nas notícias, dos hiperlinks que dão acesso direto às narrativas do Facebook. De posse dessas verificações relacionadas ao uso das postagens nas notícias, estabelecemos interpretações e conclusões dessas composições narrativas feitas pelo jornalismo. Seguimos, então, para a apresentação do caso, fundamental para nosso entendimento das circunstâncias dos enunciados jornalísticos em análise.

\title{
A narrativa de um relacionamento exposta no Facebook
}

No dia 16 de agosto de 2017, às 14h33, a atriz e escritora Clara Corleone, ex-mulher de Felipe Zancanaro, guitarrista da banda Apanhador Só ${ }^{2}$, postou um texto em sua conta pessoal no Facebook $^{3}$ relatando detalhes do relacionamento que manteve com o músico durante cinco anos; eles se separaram em $2015^{4}$. O longo relato, narrado em primeira pessoa, traz detalhes íntimos da vida do casal e revelações de infidelidade, como se pode verificar no trecho se seguir:

\begin{abstract}
aí finalmente, numa noite em que ele havia voltado de turnê, saímos pra jantar. lá, ao desconfiar de uma história muito sem pé nem cabeça, perguntei pela enésima vez consecutiva: "você me traiu?" e, finalmente, veio. foi um atrás da outra, só na cabeça - sim. muitas vezes. mais de quarenta mulheres. na frente de toda a banda. trepando no banheiro, no hotel. sim. muitas vezes não usei camisinha.

depois disso, me senti tão incrivelmente mal que me tornei um troço qualquer, tipo um fantasminha de mim mesma. fiquei muito magra. e não contei pra ninguém. não contei pra ninguém. nem pra mãe, nem pra preta, nem pro fisch, ninguém. passamos mais seis meses juntos. foi o pior período da minha vida. eu me sentia uma merda, uma bosta, uma incapaz, uma nojenta. eu tentava fazer o meu casamento dar certo, eu chorava no banheiro do trabalho, eu fazia tudo pra agradar ele, ele me dizia que agora estava tudo bem, pois era não contar aquelas coisas que fazia ele sofrer, e
\end{abstract}

2A Apanhador Só é uma banda independente muito conhecida no Rio Grande do Sul; fundada em 2003, em Porto Alegre, o grupo tem cinco discos gravados, todos disponibilizados para download gratuito pelo site http://www.apanhadorso.com/. O último álbum Meio que tudo é um foi lançado no início de agosto de 2017, poucos dias antes do depoimento de Clara ter sido publicado no Facebook. A banda já estava em turnê de lançamento do disco quando se viu envolvida pela grande repercussão do caso envolvendo um de seus integrantes. A música Linda, Louca e Livre, referenciada na postagem de Clara Corleone, é uma das 15 canções do novo e recente disco.

3 https://www.facebook.com/clara.corleone.3/posts/1630787660287778.

4Todos os nomes das pessoas citadas neste artigo foram divulgados pelas notícias na época do acontecimento. Além disso, as postagens feitas por eles estavam no modo público no Facebook. 
agora ele estava bem. Ele nunca me pediu perdão. Ele nunca prometeu não fazer mais. (CORLEONE, 2017)

Clara também relembra na postagem duas situações envolvendo agressões físicas de Felipe: na primeira, o músico teria quebrado seu dedo sem querer, em uma discussão, porque não mediu forças quando a segurou pelo braço; na segunda, ele teria desferido um soco em seu nariz ${ }^{5}$, de forma acidental, durante uma festa. No final da postagem, Clara justifica o desabafo apontando hipocrisia da banda ao gravar uma das músicas do disco novo, lançado no início de agosto deste ano, intitulada "Linda, Louca e Livre", um dos lemas do feminismo latino-americano.

\begin{abstract}
Por isso, senhoras e senhores, é que considero um tapa na minha cara que a banda do Felipe, a apanhador só, escreva e toque e grave uma música que se chama "linda, louca e livre", um dos gritos de guerra das feministas. Não há nada de feminista ou de desconstruído nesse músico e, mesmo que não seja ele o autor da canção, acho uma piada de mal gosto imensa que o felipe fique no palco tocando ela durante os shows. acho histérico. o felipe teve um relacionamento aberto com uma mulher que acreditava estar vivendo um relacionamento fechado. Foi cruel, irresponsável com os meus sentimentos, desleal, covarde. (CORLEONE, 2017)
\end{abstract}

A narrativa, repleta de episódios impactantes (deslealdade, traição, desrespeito, violência verbal e psicológica etc), descreve a situação de sofrimento de quem a relata e permite que o leitor construa, a partir de sua interpretação e disposições individuais, o caráter do músico, associando-o a um homem machista, cruel, agressor, covarde e hipócrita.

A postagem de Clara teve mais de 57 mil curtidas, cerca de 7.800 compartilhamentos e mais de 2.500 comentários, conforme observação realizada em setembro de 2017. A rápida repercussão e circulação da publicação no Facebook fez com que a banda suspendesse shows já marcados e cancelasse as atividades por tempo indeterminado; essa decisão foi comunicada pela banda, via Facebook ${ }^{6}$, no dia seguinte, 17 de agosto, às $18 \mathrm{~h} 01$.

Lamentamos profundamente tudo o que aconteceu e está acontecendo. Diante dessa difícil situação, resolvemos suspender as atividades da banda por hora. Embora pesarosos, achamos que essa situação pode ser construtiva pra que siga se discutindo questões importantes sobre machismo - que estamos dispostos a rever e modificar cada vez mais em cada um de nós. Assim que for possível, nos pronunciaremos melhor sobre o assunto (APANHADOR SÓ, 2017).

5No dia 19 de agosto, diante da repercussão das agressões subentendidas a partir de seu depoimento, Clara postou novo texto no Facebook, esclarecendo que seus machucados são decorrentes de atos não intencionais da parte de Felipe; ela afirma que sua postagem original não deixa dúvida de que tanto o soco que atingiu seu nariz como o dedo quebrado foram sem querer.

6https://www.facebook.com/apanhadorso/posts/1451608488254820. 
A manifestação de Felipe sobre o caso foi publicada em sua conta pessoal ${ }^{7}$ um pouco antes, às $16 \mathrm{~h} 46$ do dia 17 . Na postagem, o músico reconhece seus erros no relacionamento e pede desculpas à Clara pelo sofrimento causado:

Cometi muitos erros dentro da minha relação com a Clara. Meu comportamento infiel causou muito sofrimento e mágoa, e não há dúvidas de que os sentimentos dela são genuínos. Me arrependo muito pelo meu comportamento na época e entendo o posicionamento da Clara, embora a complexidade de uma relação não caiba em um post de Facebook. Hoje, três anos depois do término da relação, num processo que desde então envolveu conversas com várias pessoas e muita reflexão, eu venho fazendo uso dessas drásticas experiências pra buscar não reproduzir mais esse tipo de comportamento. (ZANCANARO, 2017).

Um novo texto foi publicado pela Apanhador Só, no dia 25 de agosto $^{8}$ de 2017, mais longo e explicativo, abordando a música em questão, citada por Clara, e convocando a todos para uma roda de conversa, realizada em Porto Alegre no dia 29 de agosto. Na postagem, a banda destaca que nunca teve a intenção que a canção "Linda, louca e livre" fosse uma música feminista pois, apesar do título, o mote é a busca por uma relação sincera e livre entre duas pessoas. O grupo também alega que não tinha conhecimento de que as palavras "libre, linda y loca" fossem um lema do feminismo latino-americano.

O episódio naturalmente causou indignação entre os fãs da Apanhador. Como geralmente ocorre no Facebook, a situação polarizou-se entre os defensores da banda, que lamentavam a suspensão das suas atividades, e as pessoas que condenavam a atitude do músico e da banda, baseadas no relato de Clara. Manifestações de solidariedade a ela puderam ser vistas na mesma medida em que palavras de ódio foram direcionadas a Felipe. Neste caso, as "histórias" do Facebook desenham as representações de vítima e algoz, bem próprias da narrativa ficcionalizada.

De acordo com Motta (2013, p.38), em todo ato discursivo, há uma vontade ontológica de criar sentido, por isso a trama narrativa se configura por agentes, meios, intenções e circunstâncias. "O sujeito narrador dispõe tática e estrategicamente a sucessão dos fatos (encadeamento, sequências, aproximação ou distanciamento do referente, etc) com o objetivo de tecer uma totalidade compreensiva". Essas disposições valem tanto para a narrativa ficcional como para a narrativa de realidade, com a diferença de que a segunda se apoia na veridicção do discurso. A narrativa jornalística é exemplo de uma organização

7https://www.facebook.com/felipezancanaro/posts/1425670097498764.

8https://www.facebook.com/apanhadorso/posts/1458331534249182. 
discursiva de fatos verídicos. No caso aqui estudado, a história a ser contada pelo jornalismo baseia-se em outras narrativas, pessoais e subjetivas, tornadas públicas pelo Facebook.

\section{A narrativa construída pelas notícias dos jornais}

O cancelamento das atividades da banda, por meio do comunicado no Facebook, e a motivação disso - a postagem de Clara, foram destaque em grandes sites de notícias como nos portais das redes Globo e Record, $\mathrm{G} 1^{9}$ e $\mathrm{R} 7^{10}$ respectivamente, em páginas de jornais do estado do Rio Grande do Sul, como nos jornais Zero Hora ${ }^{11}$ e Correio do Povo ${ }^{12}$, de jornais de circulação nacional como Folha de S.Paulo, Estadão, O Globo, em sites de revistas femininas como Marie Claire ${ }^{13}$ e Estilo ${ }^{14}$ e em sites especializados em música como na revista The Rolling Stone Brasil. Para este estudo, escolhemos as notícias dos websites da Folha, do Estadão e do Jornal O Globo, publicadas em 17 de agosto de 2017, um dia depois da postagem de Clara no Facebook.

O caso em questão suscita tópicos de relevância social e cultural, que interessam ao jornalismo, como machismo, relacionamento abusivo, violência física e psicológica contra mulheres, limites entre o público e privado, além do apontamento das contradições entre a obra artística, a música, e as posturas, atitudes, pensamentos e comportamentos do artista, neste caso, um dos integrantes da banda. Estas questões, apesar de integrarem o contexto do episódio, não foram abordadas neste artigo que tem como foco o uso das narrativas pessoais, de Clara, de Felipe e também da banda, na construção do texto jornalístico e os efeitos de sentido que podem ser apreendidos a partir dessas assimilações.

Nas três notícias aqui analisadas, identificamos os dois principais fatos que justificaram a publicação das notícias por esses três jornais brasileiros de referência: a interrupção ou suspensão das atividades da banda e o respectivo motivo: o conhecimento

9http://g1.globo.com/musica/noticia/apanhador-so-suspende-atividades-apos-guitarrista-ser-acusado-deagressao.ghtml.

10http://diversao.r7.com/pop/banda-apanhador-so-suspende-atividades-apos-guitarrista-ser-acusado-deagressao-e-traicao-18082017.

11 http://zh.clicrbs.com.br/rs/entretenimento/musica/noticia/2017/08/apos-polemica-nas-redes-sociais-e-showcancelado-banda-apanhador-so-decide-suspender-atividades-9872811.html.

12http://www.correiodopovo.com.br/ArteAgenda/Variedades/Musica/2017/8/626157/Apos-guitarrista-seracusado-de-agressao,-Apanhador-So-interrompe-atividades.

13http://revistamarieclaire.globo.com/Noticias/noticia/2017/08/apanhador-so-relato-de-relacionamento-abusivoleva-banda-suspender-atividades.html.

14https://estilo.uol.com.br/comportamento/noticias/redacao/2017/08/17/banda-tem-show-cancelado-e-anuncia-

pausa-apos-denuncia-de-relacao-abusiva.htm. 
público de detalhes do relacionamento amoroso de um dos músicos por meio de uma postagem no Facebook. Nos textos noticiosos, destacamos os três personagens envolvidos: Clara, Felipe e a banda Apanhador Só. Esses atores fizeram uso de seus canais no Facebook para se manifestarem sobre o caso e tais manifestações basearam a construção das notícias desses jornais acerca do acontecimento.

No exame das notícias, verificamos quais elementos desses relatos foram ressaltados pelo jornalista narrador, tanto no título como no corpo do texto, e observamos a presença da inserção dos hiperlinks das postagens do Facebook nos textos noticiosos. O objetivo foi perceber como as narrativas pessoais dos atores envolvidos foram apropriadas pelos jornais na construção das notícias sobre o caso.

\section{Jornal O Globo: acusação e negação}

A notícia do jornal $\mathrm{O}_{\text {Globo }}{ }^{15}$, publicada às $18 \mathrm{~h} 25$ do dia 17 de agosto e atualizada às 9h do dia 18, destaca no título (Figura 1) a "acusação de agressão" de Felipe a Clara, uma interpretação do jornal da parte do relato referente ao dedo quebrado em uma das discussões do casal.

\section{Figura 1 - Título da notícia publicada pelo jornal O Globo \\ Apanhador Só interrompe atividades após acusação de agressão \\ Pausa na carreira da banda, destaque da cena nacional, foi motivada por depoimento no Facebook de ex-mulher do guitarrista}

Fonte: site do Jornal O Globo em 18 de agosto de 2017

No lead da notícia, o destaque ao anúncio da suspensão temporária das atividades e shows, inclusive de uma segunda apresentação que seria realizada no Rio de Janeiro no dia 17. Logo em seguida, o texto expõe o motivo do cancelamento: o "depoimento" - palavra 
utilizada pelo jornal - postado por Clara no Facebook, e enquadra os episódios narrados como acusações.

\begin{abstract}
Ela acusou seu ex-marido, o guitarrista Felipe Zancanaro (integrante do Apanhador Só), de manter um relacionamento abusivo com ela - que incluía traições, violência psicológica e um caso de violência física ("tentou me segurar, não mediu força e quebrou meи dedo", escreve ela). (O GLOBO, 2017, grifo nosso).
\end{abstract}

Nessa parte do texto do Globo, há a primeira citação direta, marcada entre aspas ${ }^{16}$, do depoimento, a qual corrobora o episódio da violência física destacado pelo jornalista/editor no título. A notícia cita a acusação de traição de Felipe, "com mais de quarenta mulheres durante as viagens da banda", mas também ressalta que a própria Clara admitiu ter traído, fazendo a segunda citação direta do depoimento. "Ela escreve: isso aconteceu três vezes, duas eu contei, uma realmente não contei - não tem comparação com o que ele fez comigo, mas de fato eu errei e uma vez fui desleal. sabe quantas vezes o felipe foi desleal comigo? tá sentada? mais de quarenta." A citação direta das palavras de Clara produz efeitos de veracidade do relato, pois dá voz a ela dentro da narrativa jornalística, e reforça o tom de gravidade da história narrada, que fica mais impactante com a quantificação do número de traições.

Em seguida, a narrativa do Globo traz a motivação da própria Clara com o depoimento: a música Linda, Louca e Livre. Nesse momento, o texto noticioso faz a terceira e última citação direta da postagem de Clara: “A atriz escreveu que isso foi um tapa na minha cara". A simbologia da expressão "levar um tapa na cara" reforça o sentimento de indignação de Clara, além de referenciar o campo lexical da violência, ainda que no contexto figurado. $\mathrm{O}$ jornalista retira do depoimento justamente o trecho que poderia traduzir ou resumir o sentimento da atriz e que dá mais pistas ao leitor do porquê da postagem. No parágrafo seguinte, o jornal menciona e comenta a manifestação de Felipe no Facebook, fazendo duas citações diretas da postagem original:

Nesta quinta, Felipe se manifestou em seu Facebook, reconhecendo que cometi muitos erros dentro da minha relação com a Clara. Ele não negou nenhuma das acusações, mas argumentou que vem fazendo uso dessas drásticas experiências pra buscar não reproduzir mais esse tipo de comportamento. (O GLOBO, 2017, grifo nosso).

16Os trechos marcados entre aspas pelas notícias dos jornais foram grifados pela autora em Itálico a fim de evitar confusão com as aspas das citações dos textos das notícias no presente artigo. 
Em meio às respostas de Felipe à postagem de Clara, o jornal destaca que ele não negou nenhuma das acusações, realçando o dever profissional do jornalismo de fornecer o outro lado da história, neste caso dando voz ao "acusado" conforme a escolha lexical feita pelo próprio narrador ou editor da notícia quando destaca as "acusações" no título. Tais palavras elencadas pelo jornalista narrador sugerem um tom de crime cometido, com "depoimento" e "acusações", sustentado por três citações diretas retiradas da postagem de Clara, que atingem o caráter e o comportamento do músico. As acusações, construídas na narrativa do jornal, são negadas por Felipe, o acusado; essa informação, própria da linguagem das notícias investigativas ou policiais, parte de uma interpretação do jornalista narrador, que procura, na manifestação do músico, as respostas para as acusações expostas. Duas citações diretas da postagem de Felipe são utilizadas pela notícia para contar a versão dele da história. O cancelamento das atividades da banda aparece como uma consequência direta das acusações alegadas. Por isso, a notícia termina com a citação, entre aspas, da íntegra da nota da banda, divulgada no dia 17 de agosto. Os hiperlinks para acesso direto às postagens pelo Facebook não são apresentados.

\section{Jornal O Estado de S.Paulo: acusação e declaração}

Assim como O Globo, o Estadão ${ }^{17}$, em publicação no dia 17 de agosto, às $19 \mathrm{~h} 15$, assinada por João Paulo Carvalho, também destaca no título a acusação de agressão que a postagem de Clara deixa interpretar e a interrupção das atividades da banda. A diferença é que no título do Estadão, a causa do fato correspondente à frase "após acusação de agressão" vem ordenada antes da consequência, a interrupção das atividades da banda, o que sugere uma importância ao motivo das ações suspensas.

17http://cultura.estadao.com.br/noticias/musica,apos-acusacao-de-agressao-banda-gaucha-apanhador-sointerrompe-atividades-por-tempo-indeterminado,70001940724. 
Figura 2 - título da notícia publicada pelo jornal O Estado de S. Paulo

\section{Após acusação de agressão, banda gaúcha Apanhador Só interrompe atividades por tempo indeterminado}

Clara Corleone, ex-mulher do guitarrista Felipe Zancanaro, diz que ele mantinha um comportamento 'abusivo'

Fonte: site do jornal Estadão em 18 de agosto de 2017.

O texto inicia com a notícia da suspensão, por tempo indeterminado, das atividades da banda e o cancelamento de show no Rio de Janeiro. No segundo parágrafo, é mencionado o motivo de tal anúncio: “A atriz e escritora Clara Corleone acusou seu ex-marido, o guitarrista Felipe Zancanaro (integrante do Apanhador Só) de traições, violência psicológica e física. Felipe, inclusive, teria quebrado o dedo da namorada em uma das discussões" (CARVALHO, 2017). Do mesmo modo que O Globo, a narrativa do Estadão também menciona a violência física e o dedo quebrado com base nas informações da postagem de Clara. Em seguida, a narrativa jornalística localiza que "em texto publicado em sua conta pessoal no Facebook", Clara revela as traições de Felipe com mais de 40 mulheres e admite que também o traiu. $\mathrm{O}$ jornalista narrador também explicita no texto a motivação da postagem: "Clara conta que decidiu divulgar o caso porque a banda gravou uma música em seu novo disco cujo título é um grito de guerra feminista Linda, Louca e Livre. Foi um tapa na minha cara, diz ela no texto" (CARVALHO, 2017, grifo nosso). A citação direta "foi um tapa na minha cara", transposta do Facebook para a narrativa jornalística confere um tom mais dramático à história. Da manifestação de Felipe no Facebook, o Estadão reproduz, com citação direta, as mesmas falas que O Globo: a admissão dos erros no relacionamento e o esforço de não reproduzir tal comportamento: "Cometi muitos erros dentro da minha relação com a Clara. Venho fazendo uso de drásticas experiências pra buscar não reproduzir mais esse tipo de comportamento, declarou" (CARVALHO, 2017). Ao escrever que Felipe "declarou" suas palavras, o jornal reforça o efeito de declaração oficial do músico, de resposta às acusações feitas pela ex-mulher.

Para sinalizar ao leitor que o Estadão obedece aos critérios profissionais jornalísticos de ouvir todos os lados dos envolvidos, a notícia informa que a reportagem procurou a assessoria da banda, mas que esta não quis se manifestar. No final do texto, consta a íntegra 
da nota da Apanhador Só, divulgada via Facebook. Fechando a narrativa, estão os hiperlinks para as publicações de Clara e da banda (Figura 3).

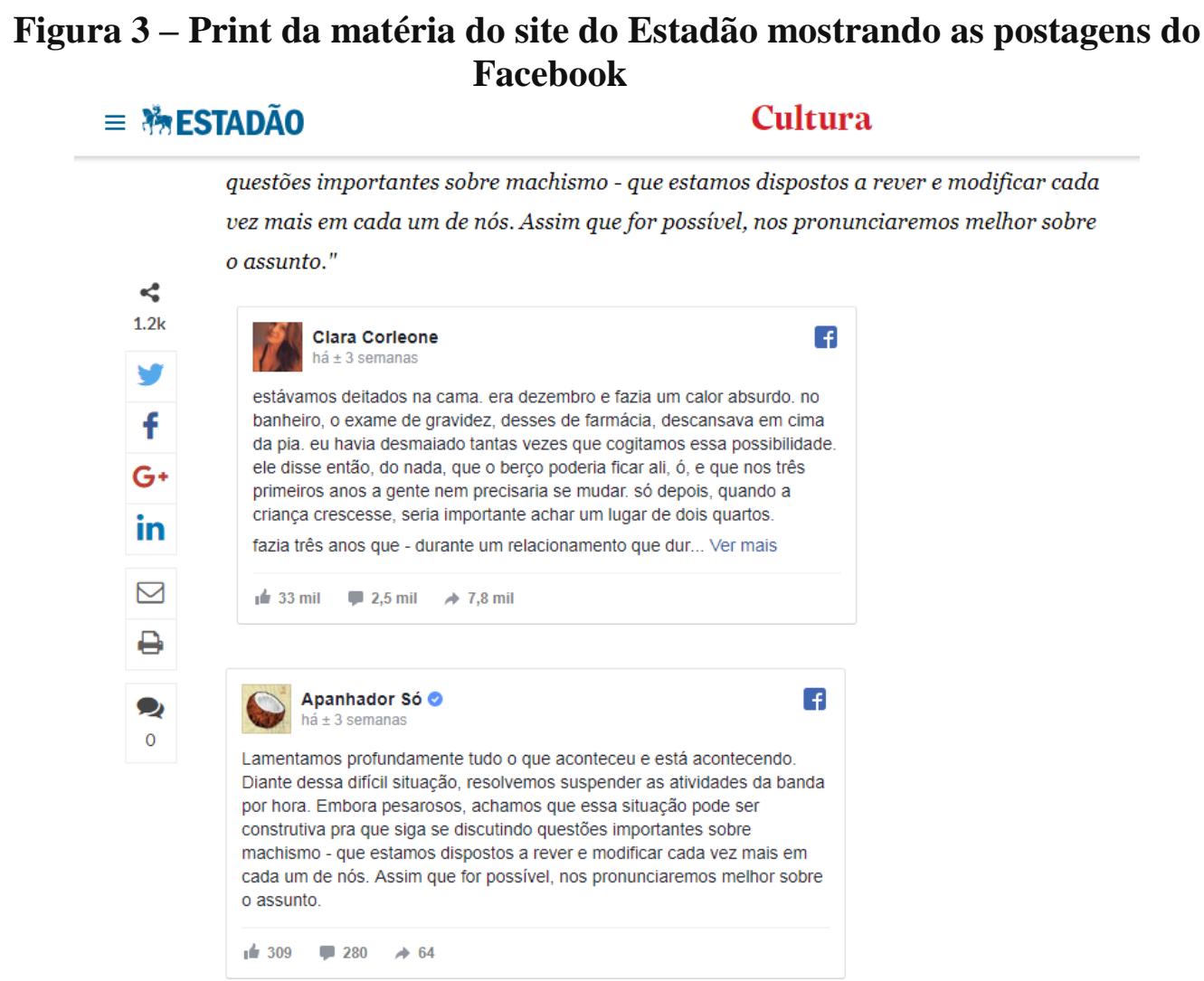

Fonte: site do Estadão dia 18 de agosto de 2017

O Estadão contou a história utilizando o discurso indireto, elencando no texto os episódios que considerou como mais importantes da narrativa de Clara: as traições de Felipe com mais de 40 mulheres, a violência psicológica e a violência física, atribuída ao relato do dedo quebrado. Além disso, a reportagem destaca a motivação da postagem: a canção Linda, Louca e Livre, que representou, para ela, o "tapa na cara” e a justificativa do longo relato sobre o relacionamento. Da manifestação de Felipe, o jornal seleciona as passagens que se referem aos "erros cometidos" e a sua busca por não repetir mais o comportamento reprovável. A nota da banda que abre com o "Lamentamos por tudo que aconteceu e está acontecendo" encerra o texto da notícia e conclui a narrativa da notícia do Estadão. Os hiperlinks aparecem abaixo da notícia e permitem que o leitor tenha a opção de acessar diretamente as postagens, públicas, do Facebook de Clara e da banda. 


\section{Jornal Folha de S.Paulo: o machismo implicado}

O site da Folha de S.Paulo $^{18}$ publicou a notícia no dia 17 de agosto, às 20h19, na editoria Ilustrada. O título (Figura 4) fala de "acusação de machismo" e não de agressão, como nos títulos do Estadão e do Globo, o que revela uma outra interpretação ou enquadramento do texto de Clara, tirando o foco de episódios específicos que são difíceis de serem comprovados, como as supostas agressões, e direcionando para o machismo - uma compreensão mais abrangente, pertencente ao campo social e cultural, e menos material do que a suposta agressão. Nomear a ação de "machismo" atenua e afasta o sentido de crime, conectado ao uso da palavra "agressão". Apesar disso, a palavra "acusação" é o agente da frase, o ato causador da suspensão das atividades da banda.

Figura 4 - Título da notícia publicada pelo jornal Folha de S. Paulo

\section{Acusação de machismo suspende atividades da banda Apanhador Só}

\section{DE SÃO PAULO}

Fonte: site do jornal Folha de S.Paulo em 18 de agosto de 2017.

O lead do texto ressalta o cancelamento dos shows da banda que se viu envolvida em uma "polêmica", nas palavras do jornal, que causou a suspensão das atividades do grupo no momento em que estava prestes a começar a turnê de divulgação do disco. No segundo parágrafo, a notícia apresenta a explicação, relatando que Clara postou "em sua rede social um depoimento sobre sua indignação perante a música 'Linda, Louca e Livre'(...)”, expressão que faz referência a um "jargão da luta feminista". Em seguida o texto noticioso revela a causa da indignação de Clara: o "relacionamento abusivo" - expressão escolhida pelo jornal, que não consta na postagem original -, que ela teria vivido, durante cinco anos, com Felipe. Ao fazer isso, a narrativa jornalística estabelece o vínculo entre essa música da banda e o relato de Clara. Assim, o jornalista narrador da Folha prioriza o enquadramento narrativo

18http://www1.folha.uol.com.br/ilustrada/2017/08/1910833-em-meio-a-lancamento-de-disco-banda-apanhadorso-e-acusada-de-machismo.shtml. 
relacionado à canção, tanto que escolhe como citação direta da postagem o trecho referente à contradição entre a música e o comportamento desleal do músico que a executa nos shows:

O felipe teve um relacionamento aberto com uma mulher que acreditava estar vivendo um relacionamento fechado. foi cruel, irresponsável com os meus sentimentos, desleal, covarde. usou de todo tipo de artimanha psicológica, eu pensei que estava ficando louca e, de fato, quase enlouqueci. não pode, agora, a banda tocar uma música que pague de bacana sobre como o homem deixa a mulher livre para ser o que ela quiser dentro duma relação, disse ela em um trecho do texto (FOLHA DE S.PAULO, 2017, grifo nosso)

Conforme podemos visualizar na Figura 5, a reportagem faz a citação direta da nota da banda e comenta sobre a manifestação de Felipe, no Facebook, apresentando o hiperlink da postagem original. A notícia ainda informa que a Folha procurou os músicos para ouvi-los em relação ao caso, mas eles não quiseram se pronunciar, o que sinaliza que o repórter tentou cumprir com os princípios básicos da apuração jornalística - ouvir todos os lados envolvidos mesmo que não tenha obtido êxito. 


\title{
Figura 5 - A inserção dos hiperlinks das postagens do Facebook na reportagem da Folha
}

\begin{abstract}
"O Felipe teve um relacionamento aberto com uma mulher que acreditava estar vivendo um relacionamento fechado. Foi cruel, irresponsável com os meus sentimentos, desleal, covarde. Usou de todo tipo de artimanha psicológica, eu pensei que estava ficando louca e, de fato, quase enlouqueci. Não pode, agora, a banda tocar uma música que pague de bacana sobre como o homem deixa a mulher livre para ser o que ela quiser dentro duma relação", disse ela em um trecho do texto (leia a íntegra abaixo).
\end{abstract}

\section{Clara Corleone}

há \pm 3 semanas

estávamos deitados na cama. era dezembro e fazia um calor absurdo. no banheiro, o exame de gravidez, desses de farmácia, descansava em cima da pia. eu havia desmaiado tantas vezes que cogitamos essa possibilidade. ele disse então, do nada, que o berço poderia ficar ali, ó, e que nos três primeiros anos a gente nem precisaria se mudar. só depois, quando a criança crescesse, seria importante achar um lugar de dois quartos.

fazia três anos que - durante um relacionamento que dur... Ver mais

It $33 \mathrm{mil} 2,5 \mathrm{mil} \rightarrow 7,8 \mathrm{mil}$

Seu post já teve mais de 31 mil curtidas e mais de 5.000 compartilhamentos. Os shows da banda previstos para esta semana no Rio de Janeiro e em Porto Alegre foram cancelados. Procurados pela Folha os músicos não quiseram se pronunciar.

Na conta oficial do grupo, postaram um comunicado: "Lamentamos profundamente tudo o que aconteceu e está acontecendo. Diante dessa difícil situação, resolvemos suspender as atividades da banda por ora. Embora pesarosos, achamos que essa situação pode ser construtiva pra que siga se discutindo questões importantes sobre machismo - que estamos dispostos a rever e modificar cada vez mais em cada um de nós. Assim que for possível, nos pronunciaremos melhor sobre o assunto".

No centro da polêmica, Zancanaro voltou a sua conta pessoal do Facebook para abordar o assunto.

Cometi muitos erros dentro da minha relação com a Clara. Meu comportamento infiel causou muito sofrimento e mágoa, e não há dúvidas de que os sentimentos dela são genuínos. Me arrependo muito pelo meu comportamento na época e entendo o posicionamento da Clara, embora a complexidade de uma relação não caiba em um post de facebook. Hoje, três anos depois do término da relação, num processo que desde então envolveu conversas com várias pessoas e muita reflexão, eu venho fazendo ... Ver mais

It 666 1,3 mil $\rightarrow 213$

Fonte: site da Folha, dia 18 de agosto de 2017.

A narrativa da Folha, pelos trechos escolhidos das postagens e palavras selecionadas, conta a história partindo da polêmica que envolveu a postagem de Clara e a música "Linda, Louca e Livre". O machismo, citado na nota da banda, e o relacionamento abusivo, praticados por um dos músicos, são o centro dessa polêmica cujo estopim, claro, é a postagem de Clara. Os hiperlinks das narrativas pessoais estão ali inseridos ao longo da notícia, intercalando o texto, como comprovantes de todas as declarações e trechos capturados pelo jornal. 
É importante destacar que o Estadão e a Folha informam em seus textos que procuraram a banda, por meio de sua assessoria, mas os músicos não quiseram se pronunciar. Essa lacuna só não compromete mais as notícias, do ponto de vista de apuração jornalística, porque justamente existem as postagens, no Facebook, de Felipe e da banda que serviram para contrapor a história relatada por Clara.

\section{Considerações finais}

Estamos diante de três narrativas jornalísticas construídas quase que integralmente por postagens do Facebook, duas delas identificadas como pessoais, ainda que divulgadas no modo público do site de rede social, de Clara e Felipe, e uma direcionada ao público, de caráter mais oficial, que é a nota da banda Apanhador Só. A postagem de Clara pode ser lida como uma história sobre um relacionamento problemático, composta por episódios fortes, descritos com certa riqueza de detalhes, envolvendo múltiplas traições, deslealdade, machucados/agressões, humilhações, clichês românticos relacionados ao papel de uma boa esposa, responsabilidades conjugais e até mesmo gravidez. Tudo contado a partir do ponto de vista, das lembranças e experiências de Clara sobre o relacionamento. A história deixa claro desde o início o causador de todo o sofrimento: o seu ex-marido, Felipe. A banda é envolvida no final do relato, quando a canção"Linda, Louca e Livre" é evocada para evidenciar uma contradição definitiva entre esse título da música, referente a um lema do feminismo, e o comportamento machista de Felipe no seu relacionamento com Clara. Já a postagem de Felipe no Facebook é baseada no arrependimento, na admissão de erros e na busca por não repetilos. A manifestação da banda é de lamento pela situação, de mea culpa e de disposição para discutir e desconstruir o machismo naturalizado entre as pessoas.

Há um forte componente de publicização da vida privada neste episódio, visto que o depoimento/narrativa de Clara no Facebook está inserido num contexto de grande produção de narrativas pessoais e manifestações individuais que são publicadas no Facebook todos os dias. O relato de Clara refere-se à dimensão privada de sua vida, da relação amorosa que teve com Felipe; a história contada por ela é repleta de detalhes e temas identificados com o universo íntimo de um casal, como a fidelidade. Para Henn (2013), a exposição pública do que é estritamente privado ganhou diferentes contornos com os sites de redes sociais. Um desses contornos é o aproveitamento de tais narrativas na prática jornalística. Certamente o 
caso tomou dimensão pública por envolver um músico pertencente a uma banda conhecida no circuito musical independente; a repercussão foi intensificada também por envolver a temática do machismo e uma canção que sugere uma postura feminista da banda, apesar da Apanhador Só ter comunicado posteriormente que a música não tem essa pretensão. O jornalismo, desse modo, tem diante de si uma história que possui aspectos da vida privada e pública dos envolvidos.

Postas em circulação no Facebook, as postagens facilitaram o trabalho de construção narrativa do episódio pelos jornais, que se utilizaram discursivamente de testemunhos e declarações já publicadas no Facebook pelos três principais envolvidos: Clara, Felipe e Apanhador Só. As notícias são construídas a partir da interpretação dessas postagens, exigindo que os jornalistas narradores selecionassem o que era mais relevante para ser enfatizado no título, quais citações se mostravam mais impactantes e importantes para serem inseridas no corpo da notícia, qual o léxico escolhido para contar a história (acusação, negação, suspensão, interrupção) e de que forma as postagens do Facebook, os materiais que comprovam a veridicção dos fatos, seriam hiperlinkadas nas matérias. Os jornais, apoiando-se sobre histórias pessoais, constroem a sua versão sobre os dados da realidade apresentada via rede social; essa versão, conforme Motta (2013), sempre será uma interpretação do real. Assim, ao se apropriar dos relatos pessoais, públicos, expostos no Facebook, os jornais reconstroem a narrativa por meio da seleção, ênfase e enquadramento aos dados brutos ofertados pelas redes sociais. Os canais jornalísticos resumem a história, selecionam e copiam as partes das postagens que julgam serem as mais relevantes, enfatizam determinados episódios e dão ordenamento ao que estava disperso pelo Facebook.

O caso exposto representa uma das práticas do jornalismo na sua relação com os sites de redes sociais: a construção de notícias a partir de conteúdos publicados nessas redes, a montagem de narrativas noticiosas com base em declarações e relatos expostos em canais pessoais. O problema reside nas reinterpretações e recriações que o jornalismo faz e o que escolhe para publicar e apresentar ao público, pois os efeitos de sentido dessas narrativas são produzidos por esse movimento de coleta, reelaboração e recirculação de vozes e dizeres. 


\section{REFERÊNCIAS}

ANDERSON, Chris; BELL, Emily; SHIRKY, Clay. Periodismo Postindustrial: Adaptación al presente. Licença Creative Commons, 2013. Disponível em: $\lfloor$ http://www.amic.media/media/files/file_352_441.pdf $>$. Acesso em: 8 ago 2017.

BARDIN, Laurence. Análise de conteúdo. Lisboa: Edições 70, 2011.

BASTOS, Helder. A diluição do jornalismo no ciberjornalismo. Estudos em jornalismo e mídia, Florianópolis, v.9, n.2, p.284-298, 2012.

BRADSHAW, Paul. Instantaneidade: efeitos da rede, jornalistas mobile, consumidores ligados e o impacto no consumo, produção e distribuição. In: CANAVILHAS, João (Org.). Webjornalismo: 7 características que marcam a diferença. Covilhã: LivrosLabcom, 2014.

BRUNS, Axel. Gatekeeping, gatewatching, realimentação em tempo real: novos desafios para o Jornalismo. Brazilian journalism research, Brasília, v.10, n.2, p.119-140, 2014.

CARVALHO, João Paulo. Após, acusação de agressão, banda gaúcha Apanhador Só interrompe atividades por tempo indeterminado, 2017. Disponível em: $<$ http://cultura.estadao.com.br/noticias/musica,apos-acusacao-de-agressao-banda-gauchaapanhador-so-interrompe-atividades-por-tempo-indeterminado,70001940724>. Acesso em 18 ago 2017.

FOLHA DE S.PAULO. Acusação de machismo suspende atividades da banda Apanhador Só, 2017. Disponível em: 〈http://www1.folha.uol.com.br/ilustrada/2017/08/1910833-em-meio-alancamento-de-disco-banda-apanhador-so-e-acusada-de-machismo.shtml>. Acesso em: 18 ago 2017.

FRANCISCATO, Carlos Eduardo. A fabricação do presente: como o jornalismo reformulou a experiência do tempo nas sociedades ocidentais. São Cristóvão: Editora UFS/Fundação Oviedo Teixeira, 2005.

GONZÁLEZ, Ángeles Cabrera. La interactividad de las audiencias en entornos de convergencia digital. Revista Icono 14, Madrid, n. 15, 2010.

HEINRICH, Ansgard. Network journalism: journalistic practice in interactive spheres. New York: Routledge, 2011.

HENN, Ronaldo. O ciberacontecimento. In: VOGEL, Daisi; MEDITSCH, Eduardo; SILVA, Gislene (orgs.). Jornalismo e acontecimento: tramas conceituais. Florianópolis: Insular, 2013. P.31-48.

LEMOS, André; LÉVY, Pierre. O futuro da internet. Em direção a uma ciberdemocracia planetária. São Paulo: Paulus, 2010.

MACHADO, Elias. O jornalismo digital em bases de dados. Florianópolis: Calandra, 2006. 
MOTTA, Luiz Gonzaga. Análise crítica da narrativa. Brasília: Editora Universidade de Brasília, 2013.

NOGUERA VIVO, José Manuel. Redes sociales como paradigma periodistico. Medios españoles en Facebook. Revista latina de comunicación social. La Laguna, n.65, p.176-186, 2010.

Disponível em: <http://www.revistalatinacs.org/10/art/891_UCAM/13_JM_Noguera.html>. Acesso em: 7 ago 2017.

O GLOBO. Apanhador Só interrompe atividades após acusação de agressão. Disponível em: $\quad$ https://oglobo.globo.com/cultura/musica/apanhador-so-interrompe-atividades-aposacusacao-de-agressao-21718188> Acesso em: 18 ago 2017.

RECUERO, Raquel. A conversação em rede. Comunicação mediada pelo computador e redes sociais na internet. Porto Alegre: Sulina, 2014a.

SHOEMAKER, Pamela $\mathbf{J}$ et al. Os leitores como gatekeepers das notícias on-line: Brasil, China e Estados Unidos. Brazilian journalism research, Brasília, v.6, n.1, p. 58-83, 2010.

SHOEMAKER, Pamela. VOS, Tim P. Teoria do gatekeeping: construção e seleção da notícia. Porto Alegre: Penso, 2011.

ZAGO, Gabriela da Silva. Circulação e recirculação de narrativas do acontecimento no jornalismo em rede: a copa do mundo 2014 no twitter. Tese de Doutorado. Programa de PósGraduação em Comunicação e Informação da Universidade Federal do Rio Grande do Sul, Porto Alegre, 2014. 